Article

\title{
The Effects of Cueing and Framing on Youth Attitudes towards Gun Control and Gun Rights
}

\author{
Stephen $\mathrm{Wu}$ \\ Department of Economics, Hamilton College, Clinton, NY 13323, USA; swu@hamilton.edu \\ Received: 21 November 2017; Accepted: 12 February 2018; Published: 15 February 2018
}

\begin{abstract}
I analyze attitudes towards gun control from a recent survey of American high school students. For students who most closely identify as Republicans, cueing them to think about prior school shootings increases their agreement that armed staff in schools will improve safety and arming citizens will reduce risk of mass shootings. For those identifying as Democrats and Independents, providing them with selective information that certain states have loose gun control laws and low rates of gun violence makes them more supportive of gun rights. For Republicans, providing selective information that certain states have loose gun control laws and high rates of gun violence makes them less supportive of gun rights. These results suggest that emotional cues may exacerbate a priori biases, while informational cues may be more likely to change people's minds about firearm policies.
\end{abstract}

Keywords: framing; cues; gun rights; gun control; youth

The current political climate reveals an increasingly divided and partisan electorate. When studying the political viewpoints of the populace, it is important to understand how beliefs are formed, and relatedly, how they might be changed. In this paper, we focus on youth attitudes towards the particular issue of gun control/gun rights. The study of youth attitudes is important because research has shown that political interest and attitudes are often shaped while young, but maintain a great deal of consistency throughout one's adult years (Prior 2010; Sears and Funk 1999).

One issue that has been at the forefront of many policy discussions in recent years is that of gun and school violence. The debate on gun control and gun rights is something that divides the U.S. Congress as well as the American public. Each year, significant time and resources are spent by lobbying groups on both sides of the debate including gun rights advocates such as the National Rifle Association and the National Association for Gun Rights, and gun control supporters such as the Brady Campaign to Prevent Gun Violence and Moms Demand Action, among others. Given the importance and relevance of the topic, it is natural to study the factors that shape attitudes towards guns, gun rights, and policies towards gun control.

In this paper, I gauge the opinions on these issues for youth across America using a recent survey of high school students administered via the Knowledge Panel ${ }^{\circledR}$, an online survey created by GfK. A random sample of slightly under 1000 high school students in grades 10-12. In addition to obtaining standard demographic characteristics such as race, gender, family income, and parental education, the survey also asks questions on attitudes towards firearm policies and gun and school violence. I also conduct random assignment of different survey versions to test whether cues and the framing of questions have any effects on survey responses. Prior research has found evidence for framing effects in determining attitudes and public opinion on a variety of issues. This paper contributes to that literature using this random assignment to study framing and cueing effects on attitudes towards a specific set of issues related to guns, gun rights, and gun control policies.

\section{Related Literature}

There are many strands of literature on the formation of political beliefs and attitudes of young people. Early theoretical work on political socialization argues that party identification develops 
in childhood through parental influence. While significant empirical evidence has supported this notion that political attitudes and party affiliations are often passed down from parents to children (Niemi and Jennings 1991; Carmines et al. 1987), research also suggests that other environmental factors play significant roles in shaping political beliefs of young people. Political beliefs of youth have been shown to be affected by schooling (Ehman 1980; Hess and Torney-Purta 1967), sense of connectedness with one's community (Flanagan et al. 2007), mass media (Pasek et al. 2006), and social media (Zhang et al. 2010).

A related literature studies the relationship between party identification and political views. Goren (2005) suggests that while party identification is very stable over time, particular political values and support for ideas such as limited government, moral tolerance, and family values are much more likely to evolve. Likewise, Johnston (2006) finds support for the idea that party identification shapes political beliefs more so than the other way around. Carsey and Layman (2006) argue that there are causal pathways in both directions between party affiliation and issue attitudes, though the direction of causality varies across types of individuals. For people who do not view a particular issue as salient to their lives, party identification takes precedence in shaping views, while those for whom an issue is salient are more likely to have their views affect their party identification. One reason to specifically study young people is because early formation of political beliefs and attitudes greatly affects attitudes in later years. Research has shown that there is a tremendous degree of persistence in civic interest (Prior 2010) and political beliefs (Sears and Funk 1999) throughout one's adult years.

Much of the aforementioned research focuses on how political beliefs are formed and evolve over time through parental upbringing, education, peers, and the media. However, a large body of literature in social and cognitive sciences has also shown the existence of psychological effects in individual decision making and attitudes. Research on motivated reasoning documents that people often cling to pre-conceived notions and beliefs and fail to process new information objectively, especially when the information is at odds with those original beliefs (Kunda 1990; Redlawsk 2002). The manner in which questions are worded and framed may also impact how individuals respond to them. The now classic framing example of Tversky and Kahneman (1981) presents the possibility of a disease outbreak that is expected to kill a certain number of people. When individuals are asked to choose between two programs that will either save 200 of lives for sure, or save either 0 or 600 lives with probabilities $2 / 3$ and $1 / 3$, respectively, individuals overwhelmingly choose the certain option. However, when the identical problem is phrased as a choice between having a certain number of people die for sure, or have an uncertain number of people die, survey respondents overwhelmingly choose the uncertain option. They proceed to explain how individuals are often risk averse to potential gains, but risk loving with respect to potential losses. Numerous authors have done follow-up research to this original study and Kühberger (1998) provides a meta-analysis of these replications.

Another branch of this research studies the effects of various types of informational and emotional cues on physiological response and subsequent behavior. Wang et al. (2015) show that viewing graphic warning labels on cigarette packages significantly decreased subjective craving responses of smokers, relative to those that viewed neutral images. Many papers have documented the connection between food cues and food consumption. For example, Fedoroff et al. (1997) shows that exposure to food cues increases appetite. Harris et al. (2009) show that food advertising increasing food consumption for both children and adults, and that the increased consumption was often for foods that were not specifically advertised. Mattes (1997) documents the presence of numerous physiological responses to food related sensory stimulation. Laibson (2001) builds an economic model of cueing on consumption, where the presence of cues increase the marginal utility of consuming cue-related goods.

Theories on the effects of framing and cueing have important implications for opinions about public policy (Chong and Druckman 2007; Druckman 2001). Differential wording of potential military action can result in big differences in opinion. Mueller (1994) discusses how most citizens were in favor of using "military force" at the start of the Persian Gulf War, but a similar majority also preferred not to "engage in combat". Jacoby (2000) shows that public opinion towards government spending 
is affected by the manner in which the issue is presented. Ferree (2003) and Rohlinger (2002) find that social movement organizations have used the power of framing to influence the media attention and the public discourse surrounding the debate on abortion rights. Several studies show that beliefs about environmental policy can be shaped by information cues to make policies feel more salient. Cornelissena et al. (2008) find that cueing people to think about the behaviors that they participate in as being environmentally friendly increases the likelihood that they deem themselves as environmentally conscious and also increases the likelihood that they engage in pro-environmental behaviors in the future. Owen et al. (2012) find that those that have recently experienced extreme weather such as heat waves or droughts are more likely to support laws to protect the environment in part because these events shape their perceptions about the importance of global warming. Related research has analyzed how frames and competing counter-frames interact to impact attitudes and behavior towards issues such as public sector reform (Vogel 2011), racial discourse (Squires 2011), and political preferences (Druckman 2004).

The effects of framing have also been shown to be dependent on party affiliations. In an experiment regarding blame attribution for governmental responses to Hurricane Katrina, Malhotra and Kuo (2008) show that providing information about party affiliation of government officials causes individuals to attribute blame to those of the opposite party, but responses are less partisan when only information about an official's responsibilities are provided. In work closely related to this study, Haider-Markel and Joslyn (2001) use a sample of Kansas residents to analyze framing effects on opinions on gun policy and blame attribution to shooting tragedies. They find evidence for framing effects for individuals who are predisposed to agree with a particular message. Specifically, they find that Republicans are more likely to support rights to carry concealed handguns when questions are presented in an "individual rights" frame, relative to being presented in a "public safety" frame, but these framing effects are not present for Democrats. Likewise, they show that the impact of framing in attributing blame for school shootings depends on the relationship between the type of framing and the predisposition of respondents. When Democrats are presented with the suggestion that many people argue that weak gun laws may have contributed to the Columbine School shootings, they are significantly more likely to attribute blame to weak gun control, relative to a control group that is simply asked to attribute blame to a number of possible factors without any cues. Meanwhile, Republicans that are presented with the suggestion that media violence may be to blame for the shootings are much more likely to attribute blame to this factor relative to those that are not presented with this frame. Importantly, Democrats are not affected by the media violence frame and Republicans are not affected by the weak gun laws frame.

Finally, the type of information and method in which it is conveyed may also affect political attitudes and behaviors. Brader (2005) conducts experiments and shows that candidates can significantly increase the force of advertisements by including music and images to evoke emotions such as fear and enthusiasm. Gadarian (2010) shows that individuals are more likely to have hawkish views on foreign policy when news stories about the possibility of terror attacks are accompanied by cues such as vivid and disturbing images of past attacks than when the same stories do not contain such images.

In this paper, I analyze the effects of several different types of cues and frames on opinions about gun rights and gun control. Within this specific literature, a number of factors have been shown to influence views on violence, guns, and gun laws. Men are generally more in accepting of the use of violence in various situations (Smith 1984) and more supportive of gun rights than women (Payne and Riedel 2002). African American youth were found to have higher scores on a questionnaire on attitudes towards guns and violence than White youth. Those with higher incomes tend to be more supportive of gun control laws (Kleck 1996; Wolpert and Gimpel 1998), and unsurprisingly, political affiliation is strongly related to attitudes towards gun policies (Cox and Piacenza 2015; Parker et al. 2017). This paper contributes to the research agenda on the formation and development of political beliefs by bridging two strands of the literature. Specifically, I test to see how the type and 
nature of particular cues or frames affect beliefs on gun rights and gun control, and also whether this interacts with one's predisposition towards a particular issue as proxied by party identification.

\section{Data Description}

The 2013 X College Youth Poll ${ }^{1}$ is one in a series of surveys aimed at learning about attitudes and opinions on various issues facing young people. Previous surveys, dating back to 1999, have focused on topics including immigration, gay rights, the U.S. economy, and attitudes towards the environment. The primary purpose of this particular survey was to assess student attitudes and perceptions towards school violence and school and public policies related to gun rights and gun control. In order to do this, the survey was conducted using the web-enabled Knowledge Panel ${ }^{\circledR}$, a randomly sampled panel designed to be representative of the U.S. population and administered by the research firm GfK. ${ }^{2}$

Initially, Knowledge Panel ${ }^{\circledR}$ participants are chosen scientifically by a random selection of telephone numbers and residential addresses. Persons in selected households are then invited by telephone or by mail to participate in the web-enabled Knowledge Panel ${ }^{\circledR}$. For those who agree to participate, but do not already have Internet access, GfK provides at no cost a laptop and ISP connection. People who already have computers and Internet service are permitted to participate using their own equipment. Panelists then receive unique log-in information for accessing surveys online, and then are sent emails throughout each month inviting them to participate in research surveys. Depending on the length and nature of the survey, participants are provided varying incentives (small cash awards, gift cards, or entry into sweepstakes drawings). The Knowledge Panel ${ }^{\circledR}$ consists of roughly 55,000 adults, as well as an additional 3000 teenagers whose parents or guardians (generally Knowledge Panel ${ }^{\circledR}$ members themselves) have provided consent for their participation. ${ }^{3}$

During the months of September, October, and November of 2013, the X College Youth Poll on Attitudes towards Guns and Gun Violence was offered to high school sophomores, juniors, and seniors from the pool of available Knowledge Panel ${ }^{\circledR}$ members. This survey was designed by students and faculty at X College in the middle of 2013 and administered through GfK's Knowledge Panel ${ }^{\circledR}$ as one of the series of surveys that panel participants could take. To encourage participation for this particular survey, respondents that completed questionnaires received a $\$ 5$ cash award. In total, 941 high school students in grades 10-12 from across the United States completed the survey, resulting in a response rate of almost $60 \%$ from the eligible population of pre-selected Knowledge Panel ${ }^{\circledR}$ participants. The resulting sample is fairly representative of the United States population of high school students, though Black students are somewhat underrepresented ( $8 \%$ of this sample compared to closer to $15 \%$ of all high school students).

The survey asked questions about general attitudes towards gun control, gun ownership, gun related violence, and exposure to guns at home and school. Background information was collected on gender, race, and family characteristics such as household income and parental education. Respondents also provided their class year, type of high school (public or private), and approximate size of the high school student body. The survey asked the respondents to rate the importance of various factors that may contribute to gun and school violence, including: being a victim of bullying, mental instability, exposure to video games or violent movies, use of alcohol or illegal drugs, and media coverage of other school shootings. There was also a question that asked about the students' knowledge of various incidents of school violence, including incidents at Columbine High School, Newtown Elementary School, and Virginia Tech University. Survey takers were also asked about their exposure to guns, including whether or not someone in their household owned a gun, whether they had ever a fired a gun, and how easy they thought it would be for a student at their school to obtain a gun.

\footnotetext{
Institution name removed to preserve anonymity.

For more information about GfK, visit: http:/ /www.gfk.com.

More technical information is available at: http:/ / www.knowledgenetworks.com/ganp/reviewer-info.html.
} 
One goal of the survey was to determine whether student attitudes may be shaped by the ordering, framing, and wording of questions. To do this, several different versions of the survey were generated and respondents were randomly given different versions. For half of the respondents, a question on the knowledge of prior school shootings ("Which of the following acts of school violence have you heard about in the news?") was placed near the beginning of the survey ('school shootings cue') as question 6 , the first question after five demographic questions. For this half of respondents, the knowledge of school shootings question directly preceded two questions asking for their level of agreement with the statements, "schools that have properly trained and armed nonteaching staff would become safer places" (question 7) and "a greater presence of armed citizens would reduce the risk of mass shootings" (question 8). For the other half of respondents, the knowledge of prior school shootings question was placed at the end of the survey (as question 42).

Another way that the survey versions varied was according to whether or not respondents were prompted with information about gun control laws and rates of gun violence within specific states before answering a question about attitudes towards the strictness of current gun control laws. One-third of respondents were randomly assigned a version that provided the information that, "Louisiana and Missouri have loose gun control laws and high rates of gun violence per capita" ('liberal information cue') before being asked whether or not they agreed that "gun control laws in most states are too strict" (question 8 for those without the school shootings cue and question 9 for those with the 'school shootings cue'). Another one-third of respondents received a version with no prompting, while the final third of the respondents were assigned a version that provided information that "Utah and South Dakota have relatively loose gun control laws and low rates of gun violence per capita" ('conservative information cue') before being asked about the strictness of gun control laws. Finally, for one-third of the sample (the same one-third provided with the 'conservative cue' in the earlier question), the statement "the Second Amendment of the U.S. Constitution protects the right of the people to keep and bear arms" (Second Amendment frame) directly preceded a question asking respondents to rate their level of agreement with the statement, "I believe that it is important for Americans to be able to practice this right." For the other two-thirds of the sample, there was no mention of the Second Amendment, and the question was worded differently: "it is important for Americans to have the right to arm themselves with guns."

In total, there were six different versions of the survey. Versions 1, 2, and 3 placed the school shootings question at the end of the survey, while Versions 4, 5, and 6 contained the 'school shootings cue' before the questions on attitudes towards gun control and gun rights. Versions 1 and 4 contained no prompt before the question on the strictness of gun control laws. Versions 2 and 5 contained the 'conservative cue' of information about two states with loose gun control laws and low rates of gun violence, as well as the 'Second Amendment cue' before the question about gun rights. Versions 3 and 6 contained the 'liberal cue' of information about two states with loose gun control laws and high rates of gun violence. Respondents were randomly assigned to take one of the six versions of the survey, with each of the versions having an equal likelihood of being selected. The resulting distribution of survey versions was roughly uniform, with 148 completing Version 1, 152 completing Version 2, 174 completing Version 3, 166 completing Version 4, 141 completing Version 5, and 160 completing Version 6 . In comparing demographic characteristics across the different survey versions, I found that there were no discernible differences in terms of variables such as school year, gender, and parental education. Full details of the survey and the specific survey questions are available from the author upon request.

\section{Empirical Methodology}

For this study, I look at a series of outcome variables related to youth attitudes towards gun rights and gun control policies. Respondents are asked to rate the degree to which they agree (strongly agree, agree, disagree, strongly disagree) with a number of statements. The first two variables that I analyze are the respondents' levels of agreement to the following statements: "Schools that have properly 
trained and armed nonteaching staff would become safer places" and "A greater presence of armed citizens would reduce the risk of mass shootings."

The independent variables included in the regressions are gender (an indicator variable equaling 1 for females, 0 for males), race (separate indicator variables for Blacks, Hispanics, and other non-Whites, with Whites as the excluded category), year in high school (indicator variables for juniors and seniors, with sophomores being the excluded category), a variable for income categories (19 total categories). I also include two indicator variables for students that most closely identify with Republicans and students that most closely identify party with Democrats (with Independents as the omitted group). Finally, I include an indicator variable that is equal to one for the randomly selected respondents that were asked about their knowledge of school shootings directly preceding the questions about their attitudes towards having armed staff in schools and armed citizens. I estimate these regressions using ordered probit models to account for the categorical nature of the outcome variables. I also augment these results with probit models for strongly agreeing with certain statements versus all of the other categories to account for the possibility that the effects of cueing and framing are concentrated at the extremes. In results not reported here, I also estimate the regressions using ordered logit models and ordinary least squares models and the substantive results are the same.

The next outcome variable that look is the level of agreement with the statement: "the Second Amendment of the U.S. Constitution protects the right of the people to keep and bear arms. I believe that it is important for Americans to be able to practice this right" (Second Amendment frame) or "it is important for Americans to have the right to arm themselves with guns" (no frame). In addition to the demographic and party identification variables included in the earlier regressions, I now include an indicator variable for the "Second Amendment Frame", which was provided to half of the sample. This is to test whether the framing of the question would affect attitudes. Again, the results are obtained using ordered probit and probit models, but ordered logit and OLS models yield similar results.

Finally, I look at one final outcome variable, which is the degree to which one agrees with the statement "gun control laws in most states are too strict." In this regression, I include two indicator variables: one for the one-third of respondents who were prompted with the information that "Louisiana and Missouri have loose gun control laws and high rates of gun violence per capita" ('liberal information cue') before being asked about the strictness of gun laws, and another for the one-third of respondents that were provided with information that "Utah and South Dakota have relatively loose gun control laws and low rates of gun violence per capita" ('conservative information cue') before being asked about the strictness of gun control laws. The omitted category includes those that received a version with no prompting before the question about the strictness of gun laws.

\section{Summary Statistics}

Table 1 shows some general statistics on the demographic characteristics of the sample as well as the distribution of answers to a number of different questions regarding gun and school violence, gun control, and gun rights. The sample consists of $8 \%$ Black students, $17 \%$ Hispanic students, and an additional $11 \%$ other non-White students. High school sophomores $(40 \%)$ and juniors (39\%) are more well represented than seniors (21\%), while approximately equal numbers of students identify most closely with the Republican Party (27\%) as with the Democratic Party (25\%), with $48 \%$ identifying with neither party, or claiming to be Independent. Fewer than 3\% of respondents failed to answer the question on party identification, while the other demographic variables are available for all of the respondents in the survey. Slightly over half of the students come from families with a yearly household income of $\$ 75,000$ or less. Male and female students are equally represented in the survey. 
Table 1. Summary statistics.

\begin{tabular}{|c|c|c|c|c|c|c|c|}
\hline VARIABLES & Obs. & $\%$ of Sample & & & & & \\
\hline Female & 481 & 48.9 & & & & & \\
\hline Male & 460 & 51.1 & & & & & \\
\hline Black Non-Hispanic & 76 & 8.1 & & & & & \\
\hline Hispanic & 157 & 16.7 & & & & & \\
\hline Other Non-White & 103 & 10.9 & & & & & \\
\hline White Non-Hispanic & 605 & 64.3 & & & & & \\
\hline Sophomore & 377 & 40.1 & & & & & \\
\hline Junior & 367 & 39.0 & & & & & \\
\hline Senior & 197 & 20.9 & & & & & \\
\hline Income Category & 12.47 & 4.26 & & & & & \\
\hline Democrat & 232 & 24.6 & & & & & \\
\hline Republican & 246 & 26.1 & & & & & \\
\hline Independent & 439 & 46.6 & & & & & \\
\hline \multirow[t]{2}{*}{ Missing Political Affiliation } & 24 & 2.6 & & & & & \\
\hline & $\begin{array}{l}\text { \%Strongly } \\
\text { Agree (4) }\end{array}$ & \%Agree (3) & $\begin{array}{l}\text { \%Disagree } \\
(2)\end{array}$ & $\begin{array}{c}\text { \%Strongly } \\
\text { Disagree (1) }\end{array}$ & $\begin{array}{l}\text { Mean } \\
(1-4)\end{array}$ & $\begin{array}{l}\text { Std. } \\
\text { Dev. }\end{array}$ & Non-Missing \\
\hline $\begin{array}{l}\text { Individuals should have right to } \\
\text { carry guns to protect property }\end{array}$ & 24.5 & 54.1 & 17.4 & 4.0 & 2.01 & 0.76 & 930 \\
\hline $\begin{array}{l}\text { Individuals should have right to } \\
\text { carry a concealed gun }\end{array}$ & 17.1 & 43.4 & 31.3 & 8.2 & 2.31 & 0.85 & 921 \\
\hline $\begin{array}{l}\text { There should be stricter } \\
\text { background checks for guns }\end{array}$ & 40.6 & 44.4 & 12.7 & 2.3 & 1.77 & 0.76 & 927 \\
\hline $\begin{array}{l}\text { Stricter gun control laws will } \\
\text { decrease gun related violence }\end{array}$ & 13.0 & 34.3 & 37.2 & 15.5 & 2.55 & 0.90 & 930 \\
\hline $\begin{array}{l}\text { Schools with properly trained } \\
\text { and armed staff would be safer }\end{array}$ & 19.4 & 54.5 & 22.4 & 4.1 & 2.11 & 0.75 & 931 \\
\hline $\begin{array}{l}\text { More armed citizens would } \\
\text { reduce risk of mass shootings }\end{array}$ & 14.2 & 36.8 & 38.6 & 10.4 & 2.45 & 0.86 & 924 \\
\hline $\begin{array}{c}\text { Schools should have metal } \\
\text { detectors for security purposes }\end{array}$ & 19.5 & 49.2 & 26.4 & 5.0 & 2.17 & 0.79 & 925 \\
\hline $\begin{array}{l}\text { There should be a ban on all } \\
\text { assault-type weapons }\end{array}$ & 29.9 & 29.9 & 29.9 & 10.3 & 2.21 & 0.99 & 924 \\
\hline Total Observations & 941 & & & & & & \\
\hline
\end{tabular}

Notes: Sample includes random sample of U.S. sophomores, juniors, and seniors.

Students are generally in agreement about the importance of protecting rights to gun ownership. $77 \%$ agree or strongly agree that individuals should have the right to carry guns in order to protect their property, while $60 \%$ agree or strongly agree that individuals should have the right the carry a concealed gun. At the same time, the vast majority of respondents believe that there should be stricter laws concerning background checks for guns ( $85 \%$ agree or strongly agree), though less than half $(47 \%)$ believe that stricter gun control laws will actually decrease gun related violence. Nearly three-quarters of students $(74 \%)$ agree or strongly agree with the statement that "schools that have properly trained and armed nonteaching staff would become safer," while the analogous number for agreement with the statement "a greater presence of armed citizens would reduce the risk of mass shootings" is $55 \%$. Slightly less than $60 \%$ agree or strongly agree that schools should have metal detectors for security purposes and the same percentage believe that there should be a ban on all assault-type weapons. These statistics are comparable to results from surveys of adult attitudes towards guns and gun policy. For example, a recent Pew Research Center study finds that $84 \%$ of adults are strongly or somewhat in favor of stricter background checks and $68 \%$ strongly or somewhat favor banning all assault weapons. The response rate for most of the questions is very high, with very few observations being lost due to missing information. As noted above, fewer than $3 \%$ of respondents failed to answer the political affiliation question ( 24 total survey takers), while the numbers of missing observations for the variables on attitudes towards gun rights and gun control are also very small (generally between $2 \%-3 \%$ of the entire sample). 


\section{Cueing and Framing Effects on Attitudes towards Guns}

I begin my analysis of the determinants of attitudes towards gun violence, gun control, and gun rights by focusing on the degree to which students agree with the statement that "schools that have more trained and armed non-teaching staff would become safer places." Table 2 shows results for an ordered probit regression which uses a 1-4 scale (strongly disagree, disagree, agree, or strongly agree) as the dependent variable, where a higher number indicates more agreement with the statement. In Column 1, I estimate this regression for all students and find those that most closely identify as Republicans are stronger in their agreement with this statement relative to Independents and this coefficient is significant at the $5 \%$ level. Female students are less likely to agree with this assessment, and this coefficient is also significant at the 5\% level. Democrats are less likely than Independents to agree with this statement, though the coefficient is not statistically significant. Meanwhile, income level, race, and class year are not important predictors in this regression.

Table 2. Emotional cues and attitudes towards arming school employees. Ordered probits: dependent variable is degree of agreement with the statement that "schools that have properly trained and armed nonteaching staff would become safer places."

\begin{tabular}{|c|c|c|c|c|}
\hline VARIABLES & (1) & (2) & (3) & (4) \\
\hline & All & Democrat & Republican & Indep. \\
\hline Female & $\begin{array}{c}-0.13 * \\
(0.07)\end{array}$ & $\begin{array}{l}0.36^{* *} \\
(0.15)\end{array}$ & $\begin{array}{c}-0.34 \text { ** } \\
(0.16)\end{array}$ & $\begin{array}{c}-0.30^{* * * *} \\
(0.11)\end{array}$ \\
\hline Black & $\begin{array}{l}-0.06 \\
(0.15)\end{array}$ & $\begin{array}{c}0.17 \\
(0.21)\end{array}$ & $\begin{array}{l}-0.41 \\
(0.87)\end{array}$ & $\begin{array}{c}-0.47^{* * *} \\
(0.23)\end{array}$ \\
\hline Hispanic & $\begin{array}{l}-0.09 \\
(0.11)\end{array}$ & $\begin{array}{l}-0.28 \\
(0.21)\end{array}$ & $\begin{array}{c}0.37 \\
(0.27)\end{array}$ & $\begin{array}{l}-0.06 \\
(0.14)\end{array}$ \\
\hline Other Non-White & $\begin{array}{c}0.10 \\
(0.12)\end{array}$ & $\begin{array}{c}0.18 \\
(0.23)\end{array}$ & $\begin{array}{c}0.09 \\
(0.36)\end{array}$ & $\begin{array}{c}0.10 \\
(0.17)\end{array}$ \\
\hline Junior & $\begin{array}{l}-0.11 \\
(0.08)\end{array}$ & $\begin{array}{c}-0.45^{* * *} \\
(0.17)\end{array}$ & $\begin{array}{l}-0.07 \\
(0.17)\end{array}$ & $\begin{array}{c}0.05 \\
(0.12)\end{array}$ \\
\hline Senior & $\begin{array}{l}-0.17 \\
(0.10)\end{array}$ & $\begin{array}{c}-0.67^{* * *} \\
(0.21)\end{array}$ & $\begin{array}{c}0.09 \\
(0.21)\end{array}$ & $\begin{array}{l}-0.00 \\
(0.14)\end{array}$ \\
\hline Income Category & $\begin{array}{l}-0.00 \\
(0.01)\end{array}$ & $\begin{array}{l}-0.02 \\
(0.02)\end{array}$ & $\begin{array}{l}-0.01 \\
(0.02)\end{array}$ & $\begin{array}{c}0.01 \\
(0.01)\end{array}$ \\
\hline Democrat & $\begin{array}{l}-0.14 \\
(0.09)\end{array}$ & & & \\
\hline Republican & $\begin{array}{l}0.34^{* * *} \\
(0.09)\end{array}$ & & & \\
\hline School Shootings Cue & $\begin{array}{l}0.20^{* * * *} \\
(0.07)\end{array}$ & $\begin{array}{l}-0.02 \\
(0.15)\end{array}$ & $\begin{array}{l}0.38 \text { ** } \\
(0.15)\end{array}$ & $\begin{array}{c}0.17 \\
(0.11)\end{array}$ \\
\hline Observations & 905 & 224 & 245 & 436 \\
\hline
\end{tabular}

Notes: Standard errors in parentheses. ${ }^{* * *} p<0.01,{ }^{* *} p<0.05,{ }^{*} p<0.1$. Omitted political affiliation is independent. Omitted class year is sophomore. Controls for mother's and father's education are also included. Dependent variable is measured on a $1-4$ scale ( $4=$ strongly agree, $1=$ strongly disagree).

A primary aim of this study is to see whether the framing and wording of questions may influence responses. As discussed earlier, half of the students were asked about their knowledge of various school shootings (such as Newtown, Columbine, and Virginia Tech) immediately before the statements, "schools that have properly trained and armed non-teaching staff would become safer places" and "a greater presence of armed citizens would reduce the risk of mass shootings." The other half of students were provided a version where the question about school shootings was at the very end of the survey. The last regression coefficient in Column 1 indicates that students who are cued to think about previous acts of school violence are significantly more likely to believe in the efficacy of having armed guards in schools. This effect is large and statistically significant. In fact, this coefficient is even larger than the coefficient for identifying as a Republican.

Previous literature (Haider-Markel and Joslyn 2001) has shown that framing and cueing effects often depend on one's predisposed beliefs and party affiliations. To test this hypothesis, I estimate the same regressions separately for the sample of Democrats, Republicans, and Independents in Columns 2, 3, and 
4, respectively. Results in Column 2 show that within the sample of Democrats, females show a stronger degree of agreement with the statement about the efficacy of having armed personnel in schools than their male counterparts, while juniors and seniors are significantly less likely to agree than sophomores. Interestingly, the effect of the 'school shootings cue' is small (an estimated coefficient of 0.04) and statistically insignificant. In Column 3, within the sample of self-identifying Republicans, females show much less agreement with this statement, while the effects of class year are not significant. Meanwhile, the 'school shootings cue' has a very large and significant effect, with a coefficient of 0.38 , which is nearly twice as large as the overall effect that is seen across the entire sample. To understand the magnitude of this effect, I have calculated the marginal effects at the mean values of the independent variables. For students identifying as Republicans, prompting them to think about prior school shootings increases the likelihood of strongly agreeing with the statement that "schools with properly trained and armed teaching and non-teaching staff would become safer places" by 14 percentage points. Column 4 shows that the size of the ordered probit coefficient for Independents is in between that for Republicans and Democrats (0.17), though it is not statistically significant. A $t$-test of the equivalence of the coefficients across the Democratic and Republican samples shows a $p$-value of 0.1 , though the coefficient for independents is not significantly different than those for either of the other two groups.

Table 3 repeats the same analysis but instead uses a binary response as the dependent variable. The variable is set equal to one if the respondent strongly agrees that having armed staff would increase school safety and zero otherwise. The results in Column 1 for all respondents show that those that are cued to think about previous school shootings are $8 \%$ more likely to strongly agree with this statement, an effect that is even larger than the effect of being Republican (relative to being Independent). Consistent with our results in Table 2, the effects are not the same across the political spectrum. In Columns 2-4, the coefficients on the 'school shootings cue' are $14 \%$ and $8 \%$ for Republicans and Independents, respectively (both statistically significant), while the analogous coefficient for the sample of Democrats is not statistically different than zero.

Table 3. Emotional cues and attitudes towards arming school employees. Probits: Dependent variable equals one if strongly agree with the statement that "schools that have properly trained and armed nonteaching staff would become safer places."

\begin{tabular}{|c|c|c|c|c|}
\hline VARIABLES & (1) & (2) & (3) & (4) \\
\hline & All & Democrat & Republican & Indep. \\
\hline Female & $\begin{array}{c}-0.05^{* *} \\
(0.03)\end{array}$ & $\begin{array}{c}0.06 \\
(0.04)\end{array}$ & $\begin{array}{l}-0.09 \\
(0.06)\end{array}$ & $\begin{array}{c}-0.09 * * \\
(0.04)\end{array}$ \\
\hline Black & $\begin{array}{l}-0.01 \\
(0.05)\end{array}$ & $\begin{array}{l}-0.02 \\
(0.05)\end{array}$ & & $\begin{array}{l}-0.06 \\
(0.07)\end{array}$ \\
\hline Hispanic & $\begin{array}{l}-0.02 \\
(0.04)\end{array}$ & $\begin{array}{c}-0.13^{* * *} \\
(0.03)\end{array}$ & $\begin{array}{c}0.07 \\
(0.10)\end{array}$ & $\begin{array}{c}0.02 \\
(0.05)\end{array}$ \\
\hline Other Non-White & $\begin{array}{l}-0.00 \\
(0.05)\end{array}$ & $\begin{array}{l}-0.01 \\
(0.07)\end{array}$ & $\begin{array}{l}-0.01 \\
(0.13)\end{array}$ & $\begin{array}{c}0.03 \\
(0.06)\end{array}$ \\
\hline Junior & $\begin{array}{c}-0.08^{* * *} \\
(0.03)\end{array}$ & $\begin{array}{c}-0.15^{* * *} \\
(0.04)\end{array}$ & $\begin{array}{l}-0.04 \\
(0.06)\end{array}$ & $\begin{array}{l}-0.04 \\
(0.04)\end{array}$ \\
\hline Senior & $\begin{array}{l}-0.02 \\
(0.03)\end{array}$ & $\begin{array}{c}-0.13^{* * *} \\
(0.03)\end{array}$ & $\begin{array}{c}0.05 \\
(0.08)\end{array}$ & $\begin{array}{c}0.07 \\
(0.05)\end{array}$ \\
\hline Income Category & $\begin{array}{l}-0.00 \\
(0.00)\end{array}$ & $\begin{array}{l}-0.01 \\
(0.01)\end{array}$ & $\begin{array}{l}-0.00 \\
(0.01)\end{array}$ & $\begin{array}{l}-0.00 \\
(0.01)\end{array}$ \\
\hline Democrat & $\begin{array}{l}-0.02 \\
(0.03)\end{array}$ & & & \\
\hline Republican & $\begin{array}{l}0.07^{* *} \\
(0.03)\end{array}$ & & & \\
\hline School Shootings Cue & $\begin{array}{c}0.08^{* * *} \\
(0.03)\end{array}$ & $\begin{array}{l}-0.01 \\
(0.04)\end{array}$ & $\begin{array}{c}0.14^{* *} \\
(0.06)\end{array}$ & $\begin{array}{l}0.08^{* *} \\
(0.04)\end{array}$ \\
\hline Observations & 905 & 224 & 243 & 436 \\
\hline
\end{tabular}

Notes: Listed coefficients are marginal effects. Standard errors in parentheses. ${ }^{* * *} p<0.01{ }^{* *} p<0.05$. Controls for mother's and father's education are also included. Omitted class year is sophomore. Omitted political affiliation is independent. 
The second dependent variable in my analysis is based on general attitudes towards arming citizens. In Table 4, I use a similar ordered probit regression to analyze the level of agreement with the statement, "A greater presence of armed citizens would reduce the risk of mass shootings", where once again a higher number indicates a greater level of agreement with the statement. Unsurprisingly, political party is a strong predictor of responses. Republicans are significantly more likely than Independents to agree with this statement, while Democrats are less likely to agree (though the coefficient is not precisely estimated), relative to Independents. Hispanics are less likely to agree than non-Hispanic Whites, while income and gender are not significant in the regressions. As for the effect of cueing respondents to think about prior school shootings, the coefficient is not statistically significant. When looking at separate regressions by party identification, the effect of the 'school shootings cue' is positive for the sample of Republicans and Independents, but negative for Democrats. Although the coefficients on the 'school shootings cue' are not significant for any of the subgroups, a $t$-test for the equivalence of the coefficient on Republicans and the coefficient on Democrats is rejected at the $10 \%$ level ( $p$-value of 0.07$)$.

Table 4. Emotional cues and attitudes towards arming citizens. Ordered probits: dependent variable is degree of agreement with the statement that "a greater presence of armed citizens would reduce the risk of mass shootings."

\begin{tabular}{|c|c|c|c|c|}
\hline VARIABLES & (1) & (2) & (3) & (4) \\
\hline & All & Democrat & Republican & Indep. \\
\hline Female & -0.09 & $0.53^{* * *}$ & -0.25 * & $-0.35^{* * *}$ \\
\hline & $(0.07)$ & $(0.15)$ & $\begin{array}{c}(0.15) \\
007\end{array}$ & $\begin{array}{l}(0.11) \\
-001\end{array}$ \\
\hline Black & $\begin{array}{c}0.09 \\
(0.15)\end{array}$ & $\begin{array}{c}0.05 \\
(0.21)\end{array}$ & $\begin{array}{c}0.07 \\
(0.80)\end{array}$ & $\begin{array}{l}-0.01 \\
(0.24)\end{array}$ \\
\hline Hispanic & $\begin{array}{c}-0.22 * * \\
(0.10)\end{array}$ & $\begin{array}{c}-0.41 \text { * } \\
(0.21)\end{array}$ & $\begin{array}{c}0.03 \\
(0.25)\end{array}$ & $\begin{array}{l}-0.15 \\
(0.14)\end{array}$ \\
\hline Other Non-White & $\begin{array}{l}-0.14 \\
(0.12)\end{array}$ & $\begin{array}{c}-0.43^{*} \\
(0.24)\end{array}$ & $\begin{array}{l}-0.22 \\
(0.35)\end{array}$ & $\begin{array}{c}0.02 \\
(0.16)\end{array}$ \\
\hline Junior & $\begin{array}{l}-0.10 \\
(0.08)\end{array}$ & $\begin{array}{l}-0.23 \\
(0.17)\end{array}$ & $\begin{array}{c}0.17 \\
(0.16)\end{array}$ & $\begin{array}{l}-0.11 \\
(0.12)\end{array}$ \\
\hline Senior & $\begin{array}{l}-0.10 \\
(0.10)\end{array}$ & $\begin{array}{c}-0.71^{* * * *} \\
(0.21)\end{array}$ & $\begin{array}{l}0.47^{* *} \\
(0.20)\end{array}$ & $\begin{array}{l}-0.00 \\
(0.14)\end{array}$ \\
\hline Income Category & $\begin{array}{c}0.00 \\
(0.01)\end{array}$ & $\begin{array}{c}0.00 \\
(0.02)\end{array}$ & $\begin{array}{l}-0.01 \\
(0.02)\end{array}$ & $\begin{array}{c}0.01 \\
(0.01)\end{array}$ \\
\hline Democrat & $\begin{array}{c}-0.24^{* *} \\
(0.09)\end{array}$ & & & \\
\hline Republican & $\begin{array}{c}0.34 * * * \\
(0.09)\end{array}$ & & & \\
\hline School Shootings Cue & $\begin{array}{c}0.08 \\
(0.07)\end{array}$ & $\begin{array}{l}-0.16 \\
(0.15)\end{array}$ & $\begin{array}{c}0.22 \\
(0.14)\end{array}$ & $\begin{array}{c}0.10 \\
(0.11)\end{array}$ \\
\hline Observations & 898 & 222 & 243 & 433 \\
\hline
\end{tabular}

\footnotetext{
Notes: Standard errors in parentheses. ${ }^{* *} p<0.01,{ }^{* *} p<0.05,{ }^{*} p<0.1$ Controls for mother's and father's education are also included. Omitted class year is sophomore. Omitted political affiliation is independent. Dependent variable is measured on a $1-4$ scale ( $4=$ strongly agree, $1=$ strongly disagree $)$.
}

In Table 5, I use a binary response as the dependent variable, where the variable equals one if the student indicates "strongly agree" with the statement that arming citizens would decrease the risk of mass shootings. Over the entire sample, respondents are 3\% more likely to strongly agree with the statement when they are cued to think about prior school shootings, though this coefficient is not statistically significant. Once again, the effects are very different across political affiliations. For self-identifying Republicans, providing students with the cue of thinking of previous school shootings leads to a statistically significant increase of $15 \%$ on the likelihood of strongly agreeing that arming citizens would decrease risk of mass shootings. There are no significant effects for Democrats or Independents. 
Table 5. Emotional cues and attitudes towards arming citizens. Probits: dependent variable equals one if strongly agree with the statement that "a greater presence of armed citizens would reduce the risk of mass shootings."

\begin{tabular}{|c|c|c|c|c|}
\hline VARIABLES & (1) & (2) & (3) & (4) \\
\hline & All & Democrat & Republican & Indep. \\
\hline Female & $\begin{array}{c}-0.05^{* *} \\
(0.02)\end{array}$ & $\begin{array}{l}0.07^{*} \\
(0.04)\end{array}$ & $\begin{array}{c}-0.11^{* *} \\
(0.05)\end{array}$ & $\begin{array}{c}-0.08^{* * *} \\
(0.03)\end{array}$ \\
\hline Black & $\begin{array}{l}-0.04 \\
(0.04)\end{array}$ & $\begin{array}{l}-0.04 \\
(0.04)\end{array}$ & & $\begin{array}{l}-0.05 \\
(0.05)\end{array}$ \\
\hline Hispanic & $\begin{array}{c}-0.06^{* *} \\
(0.03)\end{array}$ & $\begin{array}{c}-0.09^{* * *} \\
(0.03)\end{array}$ & $\begin{array}{l}-0.05 \\
(0.07)\end{array}$ & $\begin{array}{l}-0.03 \\
(0.03)\end{array}$ \\
\hline Other Non-White & $\begin{array}{c}-0.10^{* * *} \\
(0.02)\end{array}$ & $\begin{array}{c}-0.07^{*} \\
(0.04)\end{array}$ & $\begin{array}{c}-0.12 \text { ** } \\
(0.05)\end{array}$ & $\begin{array}{c}-0.10^{* * *} \\
(0.03)\end{array}$ \\
\hline Junior & $\begin{array}{c}-0.05^{*} \\
(0.02)\end{array}$ & $\begin{array}{c}-0.07^{*} \\
(0.04)\end{array}$ & $\begin{array}{c}0.03 \\
(0.06)\end{array}$ & $\begin{array}{c}-0.05^{*} \\
(0.03)\end{array}$ \\
\hline Senior & $\begin{array}{c}0.01 \\
(0.03)\end{array}$ & $\begin{array}{c}-0.07^{* *} \\
(0.03)\end{array}$ & $\begin{array}{l}0.22 * * \\
(0.09)\end{array}$ & $\begin{array}{l}-0.01 \\
(0.04)\end{array}$ \\
\hline Income Category & $\begin{array}{c}0.00 \\
(0.00)\end{array}$ & $\begin{array}{l}-0.00 \\
(0.00)\end{array}$ & $\begin{array}{c}0.00 \\
(0.01)\end{array}$ & $\begin{array}{c}0.00 \\
(0.00)\end{array}$ \\
\hline Democrat & $\begin{array}{c}0.01 \\
(0.03)\end{array}$ & & & \\
\hline Republican & $\begin{array}{l}0.05^{*} \\
(0.03)\end{array}$ & & & \\
\hline School Shootings Cue & $\begin{array}{c}0.03 \\
(0.02)\end{array}$ & $\begin{array}{c}-0.03 \\
(0.04)\end{array}$ & $\begin{array}{c}0.15^{* * *} \\
(0.05)\end{array}$ & $\begin{array}{c}0.01 \\
(0.03)\end{array}$ \\
\hline Observations & 898 & 222 & 241 & 433 \\
\hline
\end{tabular}

Notes: Listed coefficients are marginal effects. Standard errors in parentheses. ${ }^{* * *} p<0.01,{ }^{* *} p<0.05,{ }^{*} p<0.1$. Controls for mother's and father's education are also included. Omitted class year is sophomore. Omitted political affiliation is independent.

Next, I test whether or not the prompting of the Second Amendment affects the degree to which individuals value the importance of gun rights. For one-third of the sample, individuals were provided with the following statement: "The Second Amendment of the U.S. Constitution protects the right of the people to keep and bear arms." This was then followed by the statement, "I believe that it is important for Americans to be able to practice this right", and respondents were asked about the degree to which they agree with that statement. For the other two thirds of the sample, there was no prompting of the Second Amendment, and the following statement was given to survey respondents: "It is important for Americans to have the right to arm themselves with guns", and respondents were asked to agree or disagree with that statement. The results of regressions that analyze the level of agreement with these slightly different statements (with and without the prompt) are shown in Tables 6 and 7. In the ordered probit regressions in Table 6, I find that after controlling for race, gender, year in school, household income, parental education, and political affiliation, those that are prompted to think about the Second Amendment are more likely to believe that it is important for Americans to practice the right to bear arms. When I estimate this separately by political party, I find that only the coefficient for Republicans is statistically significant, though the coefficients for the Democrat, Republican, and Independent samples are not statistically different from one another. In Table 7, those that are given the 'Second Amendment cue' are 8\% more likely to strongly agree with this statement than those that are not cued. When limiting the analysis to those of similar political persuasion, we see that again, this effect is large and significant for self-identified Republicans, but insignificant for Democrats and Independents. Republicans are $17 \%$ more likely to believe in the importance in protecting the right to bear arms when it is framed as a Constitutional right than when it is not. 
Table 6. Framing effects and attitudes towards gun ownership rights. Ordered probits: dependent variable is degree of agreement with the statement "the Second Amendment of the U.S. Constitution protects the right of the people to keep and bear arms. I believe that it is important for Americans to be able to practice this right" (Second Amendment frame) or "it is important for Americans to have the right to arm themselves with guns" (no frame).

\begin{tabular}{|c|c|c|c|c|}
\hline VARIABLES & (1) & (2) & (3) & (4) \\
\hline & All & Democrat & Republican & Indep. \\
\hline Female & $\begin{array}{l}-0.12 \\
(0.08)\end{array}$ & $\begin{array}{l}-0.00 \\
(0.15)\end{array}$ & $\begin{array}{c}0.07 \\
(0.16)\end{array}$ & $\begin{array}{c}-0.26^{* *} \\
(0.11)\end{array}$ \\
\hline Black & $\begin{array}{l}-0.15 \\
(0.15)\end{array}$ & $\begin{array}{c}0.22 \\
(0.21)\end{array}$ & $\begin{array}{c}-1.68^{*} \\
(0.88)\end{array}$ & $\begin{array}{c}-0.61 \text { ** } \\
(0.24)\end{array}$ \\
\hline Hispanic & $\begin{array}{l}-0.07 \\
(0.11)\end{array}$ & $\begin{array}{l}-0.02 \\
(0.21)\end{array}$ & $\begin{array}{c}0.04 \\
(0.27)\end{array}$ & $\begin{array}{l}-0.12 \\
(0.14)\end{array}$ \\
\hline Other Non-White & $\begin{array}{c}-0.32 * * \\
(0.12)\end{array}$ & $\begin{array}{l}-0.43 * \\
(0.23)\end{array}$ & $\begin{array}{l}-0.49 \\
(0.36)\end{array}$ & $\begin{array}{l}-0.26 \\
(0.17)\end{array}$ \\
\hline Junior & $\begin{array}{l}-0.02 \\
(0.08)\end{array}$ & $\begin{array}{c}0.02 \\
(0.17)\end{array}$ & $\begin{array}{c}0.10 \\
(0.17)\end{array}$ & $\begin{array}{l}-0.10 \\
(0.12)\end{array}$ \\
\hline Senior & $\begin{array}{l}-0.16 \\
(0.10)\end{array}$ & $\begin{array}{l}-0.27 \\
(0.21)\end{array}$ & $\begin{array}{c}0.23 \\
(0.22)\end{array}$ & $\begin{array}{c}-0.25^{*} \\
(0.15)\end{array}$ \\
\hline Income Category & $\begin{array}{l}-0.00 \\
(0.01)\end{array}$ & $\begin{array}{l}-0.01 \\
(0.02)\end{array}$ & $\begin{array}{l}-0.00 \\
(0.02)\end{array}$ & $\begin{array}{l}-0.00 \\
(0.02)\end{array}$ \\
\hline Democrat & $\begin{array}{c}-0.43^{* * *} \\
(0.09)\end{array}$ & & & \\
\hline Republican & $\begin{array}{c}0.41^{* * *} \\
(0.09)\end{array}$ & & & \\
\hline Second Amendment Frame & $\begin{array}{c}0.21^{* * *} \\
(0.08)\end{array}$ & $\begin{array}{c}0.25 \\
(0.17)\end{array}$ & $\begin{array}{l}0.32 * \\
(0.17)\end{array}$ & $\begin{array}{c}0.19 \\
(0.12)\end{array}$ \\
\hline Observations & 900 & 225 & 245 & 430 \\
\hline
\end{tabular}

Notes: Standard errors in parentheses. ${ }^{* *} p<0.01,{ }^{* *} p<0.05,{ }^{*} p<0.1$ Controls for mother's and father's education are also included. Omitted class year is sophomore. Omitted political affiliation is independent. Dependent variable is measured on a $1-4$ scale ( $4=$ strongly agree, $1=$ strongly disagree $)$.

Table 7. Framing effects and attitudes towards gun ownership rights. Probits: dependent variable equals one if strongly agree with the statement that "it is important for Americans to have the right to arm themselves with guns."

\begin{tabular}{|c|c|c|c|c|}
\hline VARIABLES & (1) & (2) & (3) & (4) \\
\hline & All & Democrat & Republican & Indep. \\
\hline Female & $\begin{array}{l}-0.04 \\
(0.03)\end{array}$ & $\begin{array}{l}-0.00 \\
(0.05)\end{array}$ & $\begin{array}{c}0.02 \\
(0.07)\end{array}$ & $\begin{array}{l}-0.06 \\
(0.05)\end{array}$ \\
\hline Black & $\begin{array}{c}-0.12^{* *} \\
(0.06)\end{array}$ & $\begin{array}{l}-0.06 \\
(0.06)\end{array}$ & & $\begin{array}{c}-0.24^{* * *} \\
(0.06)\end{array}$ \\
\hline Hispanic & $\begin{array}{l}-0.03 \\
(0.04)\end{array}$ & $\begin{array}{c}-0.10 \text { * } \\
(0.05)\end{array}$ & $\begin{array}{c}0.05 \\
(0.12)\end{array}$ & $\begin{array}{l}-0.03 \\
(0.06)\end{array}$ \\
\hline Other Non-White & $\begin{array}{c}-0.09 * \\
(0.05)\end{array}$ & $\begin{array}{c}-0.11^{* *} \\
(0.05)\end{array}$ & $\begin{array}{c}-0.25 * \\
(0.13)\end{array}$ & $\begin{array}{l}-0.06 \\
(0.07)\end{array}$ \\
\hline Junior & $\begin{array}{l}-0.02 \\
(0.03)\end{array}$ & $\begin{array}{l}-0.02 \\
(0.06)\end{array}$ & $\begin{array}{c}0.08 \\
(0.08)\end{array}$ & $\begin{array}{l}-0.06 \\
(0.05)\end{array}$ \\
\hline Senior & $\begin{array}{l}-0.02 \\
(0.04)\end{array}$ & $\begin{array}{c}-0.13^{* * *} \\
(0.05)\end{array}$ & $\begin{array}{c}0.12 \\
(0.09)\end{array}$ & $\begin{array}{l}-0.02 \\
(0.06)\end{array}$ \\
\hline Income Category & $\begin{array}{l}-0.00 \\
(0.00)\end{array}$ & $\begin{array}{l}-0.00 \\
(0.01)\end{array}$ & $\begin{array}{c}0.00 \\
(0.01)\end{array}$ & $\begin{array}{l}-0.00 \\
(0.01)\end{array}$ \\
\hline Democrat & $\begin{array}{c}-0.14^{* * *} \\
(0.04)\end{array}$ & & & \\
\hline Republican & $\begin{array}{c}0.13^{* * *} \\
(0.04)\end{array}$ & & & \\
\hline Second Amendment Frame & $\begin{array}{l}0.08^{* *} \\
(0.03)\end{array}$ & $\begin{array}{c}0.05 \\
(0.06)\end{array}$ & $\begin{array}{l}0.17^{* *} \\
(0.07)\end{array}$ & $\begin{array}{c}0.05 \\
(0.05)\end{array}$ \\
\hline Observations & 900 & 189 & 243 & 430 \\
\hline
\end{tabular}

Notes: Listed coefficients are marginal effects. Standard errors in parentheses. ${ }^{* * *} p<0.01,{ }^{* *} p<0.05,{ }^{*} p<0.1$. Controls for mother's and father's education are also included. Omitted class year is sophomore. Omitted political affiliation is independent. 
As discussed earlier, prior research suggests that the nature and type of cues may result in different effects on people's attitudes towards political issues. The first two types of cues, a reminder of past acts of gun violence and a prompt regarding the Second Amendment of the Constitution, are ones that appeal primarily to one's emotions. In these cases, the results suggest that such cues increase the degree to which Republicans (more likely to be predisposed to supporting gun ownership rights) believe that arming citizens and/or school staff would provide a safer environment. However, these cues do not significantly impact the beliefs of Democrats, while the effects for Independents are mixed. I now analyze the effect of a different type of cue: one that provides objective, albeit selective, information that may be relevant to one's views on gun control. All respondents were asked to agree or disagree with the statement "I believe that gun control laws in most states are too strict." For one-third of the sample (the 'conservative information cue'), this statement was preceded with the information that "Utah and South Dakota have relatively loose gun control laws and low rates of gun violence per capita." For another third of the sample (the 'liberal information cue'), respondents were provided with the information that "Louisiana and Missouri have loose gun control laws and high rates of gun violence per capita." For the final third of the sample, there was no corresponding informational cue about specific states. Once again, the assignment of these survey versions was random. ${ }^{4,5}$

Column 1 of Table 8 shows the results of ordered probits for the entire sample. As before, political affiliation is a strong predictor of attitudes towards guns and gun laws. Republicans are significantly more likely than Independents to agree that gun control laws are too strict, while Democrats significantly less likely to agree. Women and other non-Whites are predicted to be less likely to agree that gun laws are too strict than men and whites, respectively. There is an interesting asymmetry in the effect of giving different types of informational prompts. Providing information that two states with loose gun control laws also have low rates of gun violence (the 'conservative cue') significantly increases respondents' likelihood to believe that gun control laws are too strict, relative to no prompting of information, but there is no effect of providing information that two states with loose gun control law happen to have high rates of gun violence (the 'liberal cue').

When I divide the sample by political party in Columns 2-4, I find results that vary significantly by political affiliation. Democrats and Independents are the ones most affected by the information given in the 'conservative cue', while the coefficient on the 'conservative cue' is insignificant for Republicans. For students that identify as Democrats or Independents, providing objective information that some states have loose gun laws yet relatively low rates of gun violence leads them to become more supportive of gun rights. Meanwhile, the liberal prompt has a negative coefficient for Republicans (though it is not statistically significant in this specification), and no effect on responses for Democrats or Independents. ${ }^{6}$ In Table 9, I do an analogous estimation of probits, where the dependent variable is equal to one if respondents strongly agree with the statement that gun laws are too strict in most states and zero otherwise (thus collapsing the other categories into one). In this specification, Independents are the group that have the strongest effects of the conservative informational prompt, while the effects are not statistically significant for Republicans or Democrats. Interestingly, for Republicans, I now find that the liberal prompt significantly decreases the likelihood of strongly agreeing with this statement.

4 Unfortunately, the initial size of the survey did not allow separate treatments of the 'conservative cue' and the Second Amendment cue, so Versions 2 and 5 combined these as two treatments together. The 'conservative cue' and subsequent question on strictness of gun control laws was near the beginning of the survey and the 'Second Amendment cue' and question about the right to bear arms was near the end of the survey. Therefore, the 'Second Amendment cue' would not be able to contaminate the results for the 'conservative cue', though there would be potential for the 'conservative cue' to contribute to the results of the Second Amendment prompt.

5 This concern also extends to the respondents who were exposed to multiple cues in the same survey. I can only identify the independent effects of a particular cue on questions asked before other cues are introduced.

6 One potential concern is that by naming specific states in the prompts, the effects will vary according to region or location of the respondents because some students will not see the information about a far-away state as relevant to their own community. In results not shown here, I find that including indicators for region of the country and interactions between region and the type of information prompt ('conservative cue' or 'liberal cue') does not affect the results. 
Calculating the marginal effect at the mean values of the covariates implies that for Republicans, the liberal prompt decreases the likelihood of strongly agreeing with the statement that gun laws are too strict by 11 percentage points. A test for the equivalence of coefficients between the samples of Republicans and Democrats is rejected with a p-value of 0.04 . So while the liberal prompt does not significantly affect the likelihood that Republicans will move within the categories of strongly disagree, disagree, or agree, they moderate the views of those that are most strongly predisposed to believe that gun laws are too strict. The combined results from Tables 8 and 9 imply that purely informational cues have a moderating effect on views towards gun control and gun rights. Democrats and Independents become more open to the idea that gun control may be too strict when given information about states with loose gun control laws and low rates of gun violence, while Republicans are more open to the idea that gun control laws are not too strict when given information about other states that have loose gun laws and high rates of gun violence.

Table 8. Information cues and attitudes towards gun control laws. Ordered probits: dependent variable is degree of agreement with the statement that "gun control laws in most states are too strict."

\begin{tabular}{|c|c|c|c|c|}
\hline VARIABLES & (1) & (2) & (3) & (4) \\
\hline & All & Democrat & Republican & Indep. \\
\hline \multirow[t]{2}{*}{ Female } & $-0.15^{* *}$ & $0.29 *$ & $-0.28 *$ & $-0.37^{* * *}$ \\
\hline & $(0.07)$ & $(0.15)$ & $(0.15)$ & $(0.11)$ \\
\hline \multirow[t]{2}{*}{ Black } & -0.13 & -0.05 & -1.35 & $-0.43^{*}$ \\
\hline & $(0.15)$ & $(0.21)$ & $(0.86)$ & $(0.24)$ \\
\hline \multirow[t]{2}{*}{ Hispanic } & -0.08 & -0.25 & 0.10 & -0.01 \\
\hline & $(0.11)$ & $(0.22)$ & $(0.26)$ & $(0.14)$ \\
\hline \multirow[t]{2}{*}{ Other Non-White } & $-0.22 *$ & $-0.58^{* *}$ & -0.01 & -0.08 \\
\hline & $(0.13)$ & $(0.24)$ & $(0.36)$ & $(0.17)$ \\
\hline \multirow[t]{2}{*}{ Junior } & -0.01 & -0.04 & 0.04 & 0.00 \\
\hline & $(0.08)$ & $(0.17)$ & $(0.16)$ & $(0.12)$ \\
\hline \multirow[t]{2}{*}{ Senior } & 0.01 & $-0.40 *$ & 0.37 * & 0.13 \\
\hline & $(0.10)$ & $(0.22)$ & $(0.21)$ & $(0.15)$ \\
\hline \multirow[t]{2}{*}{ Income Category } & -0.00 & -0.02 & 0.02 & -0.00 \\
\hline & $(0.01)$ & $(0.02)$ & $(0.02)$ & $(0.02)$ \\
\hline Democrat & $\begin{array}{c}-0.44^{* * *} \\
(0.09)\end{array}$ & & & \\
\hline Republican & $\begin{array}{c}0.35^{* * *} \\
(0.09)\end{array}$ & & & \\
\hline \multirow[t]{2}{*}{ Conservative Information Cue } & $0.35^{* * *}$ & $0.48^{* *}$ & 0.16 & $0.45^{* * *}$ \\
\hline & $(0.09)$ & $(0.20)$ & $(0.19)$ & $(0.14)$ \\
\hline \multirow[t]{2}{*}{ Liberal Information Cue } & 0.03 & 0.04 & -0.24 & 0.12 \\
\hline & $(0.09)$ & $(0.19)$ & $(0.18)$ & $(0.13)$ \\
\hline Observations & 902 & 225 & 244 & 433 \\
\hline
\end{tabular}

Notes: Standard errors in parentheses. ${ }^{* * *} p<0.01,{ }^{* *} p<0.05,{ }^{*} p<0.1$ Controls for mother's and father's education are also included. Omitted class year is sophomore. Omitted political affiliation is independent. Dependent variable is measured on a $1-3$ scale ( 3 = strongly agree, 1 = strongly disagree).

Taken together, my empirical analysis shows that the prompting of information and the framing and ordering of questions can have significant effects on attitudes towards guns and gun control, but these effects vary across the political spectrum and they depend on the nature of information provided as cues. Young people that most closely identify as Republicans are strengthened in their support of gun rights when prompted to think about prior acts of school violence and cued to think about the Second Amendment of the Constitution, but Democrats are not significantly affected by these cues. The magnitudes and significance of the effects for Independents lies somewhere in between. Meanwhile, Democrats and Independents are more likely to be convinced that gun control laws are too strict when presented with information that certain states have loose gun control laws and low rates of gun violence, while Republicans become less strong in their convictions that gun control laws 
are too strict when given information about states with loose gun control laws and high rates of gun violence. One interpretation of these results is that emotional cues are more likely to exacerbate initial biases of individual attitudes towards gun laws, while information cues are more likely to change people's minds about this controversial issue.

Table 9. Information cues and attitudes towards gun control laws. Probits: dependent variable is equal to one for those that strongly agree with the statement that "gun control laws in most states are too strict."

\begin{tabular}{|c|c|c|c|c|}
\hline VARIABLES & (1) & (2) & (3) & (4) \\
\hline & All & Democrat & Republican & Indep. \\
\hline \multirow[t]{2}{*}{ Female } & -0.20 & $1.30 * *$ & -0.26 & $-0.46^{* *}$ \\
\hline & $(0.13)$ & $(0.59)$ & $(0.25)$ & $(0.19)$ \\
\hline \multirow[t]{2}{*}{ Black } & -0.09 & -1.03 & & -0.39 \\
\hline & $(0.27)$ & $(0.74)$ & & $(0.49)$ \\
\hline \multirow[t]{2}{*}{ Hispanic } & -0.25 & & 0.07 & -0.13 \\
\hline & $(0.18)$ & & $(0.38)$ & $(0.24)$ \\
\hline \multirow[t]{2}{*}{ Other Non-White } & -0.23 & & -0.11 & -0.18 \\
\hline & $(0.23)$ & & $(0.56)$ & $(0.28)$ \\
\hline \multirow[t]{2}{*}{ Junior } & -0.10 & -0.60 & 0.03 & -0.08 \\
\hline & $(0.14)$ & $(0.49)$ & $(0.28)$ & $(0.20)$ \\
\hline \multirow[t]{2}{*}{ Senior } & 0.19 & & $0.59 *$ & 0.31 \\
\hline & $(0.16)$ & & $(0.31)$ & $(0.23)$ \\
\hline \multirow[t]{2}{*}{ Income Category } & 0.01 & -0.09 & $0.08^{* *}$ & -0.01 \\
\hline & $(0.02)$ & $(0.07)$ & $(0.04)$ & $(0.02)$ \\
\hline \multirow[t]{2}{*}{ Democrat } & $-0.46^{* *}$ & & & \\
\hline & $(0.19)$ & & & \\
\hline \multirow[t]{2}{*}{ Republican } & 0.18 & & & \\
\hline & $(0.14)$ & & & \\
\hline \multirow[t]{2}{*}{ Conservative Information Cue } & 0.25 * & 0.57 & -0.10 & $0.46^{* *}$ \\
\hline & $(0.15)$ & $(0.58)$ & $(0.27)$ & $(0.23)$ \\
\hline \multirow[t]{2}{*}{ Liberal Information Cue } & -0.08 & -0.84 & $-0.79^{* * *}$ & 0.32 \\
\hline & $(0.16)$ & $(0.84)$ & $(0.30)$ & $(0.23)$ \\
\hline Observations & 902 & 107 & 242 & 433 \\
\hline
\end{tabular}

Notes: Standard errors in parentheses. ${ }^{* *} p<0.01,{ }^{* *} p<0.05,{ }^{*} p<0.1$ Controls for mother's and father's education are also included. Omitted class year is sophomore. Omitted political affiliation is independent. Dependent variable is measured on a 1-3 scale ( 3 = strongly agree, 1 = strongly disagree).

In addition to the main results reported here, I have also conducted a series of ancillary regressions to check to see whether the effects of these prompts interact with other independent variables such as age, gender, race, or family income. These regressions do not show any significant results for these interactions, though the relatively small number of non-Whites (particularly the underrepresentation of Black students) in the sample decreases the power to look at interactions with race. Another possibility is that the two experimental treatments may interact with one another. However, I did not find that that the school shooting cues affected the way students reacted to the later treatments of the Second Amendment frame or the conservative or liberal gun control prompts.

\section{Conclusions}

In this paper, I have conducted an analysis of youth attitudes towards guns and gun and school violence using a new data set of American High School seniors, juniors, and sophomores. Female students are less likely to believe that arming school staff would make schools safer and are generally less supportive of gun rights, consistent with prior literature (Smith 1984; Payne and Riedel 2002). Black teenagers do not have significantly different views on guns and gun rights than White teenagers, though I do find that Hispanics and other non-Whites are somewhat less supportive of gun rights than Whites. I do not find variation in attitudes according to family income. A consistent result in this study is that attitudes are strongly related to self-identified political preferences, a finding strongly 
supported by other research (Cox and Piacenza 2015; Parker et al. 2017). Students that most closely identify as Republicans are more likely to agree that arming citizens and arming school personnel would be effective in decreasing mass shootings and school violence than Democrats. Meanwhile, self-identifying Democrats are more likely than Republicans to believe that gun control laws should be stricter in many states. However, individual responses are also significantly shaped by the framing of the survey questions and the prompting of certain relevant information. The nature of cues and the political party identification determine the impacts that they have on student responses. Prompting students to think about prior acts of school violence increase the likelihood that Republicans agree about the efficacy of arming citizens to reduce violence, and to a lesser to degree for Independents, but this effect is not present for Democrats. Likewise, prompting students to think about the Second Amendment of the U.S. Constitution increases their assessment of the importance of individual gun rights for Republicans, but not for Democrats or Independents. When looking at the effect of informational cues, I find that providing selective information that certain states have loose gun control laws and low rates of gun violence increases the agreement that gun control laws are too strict in most states for Democrats and Independents, but not for Republicans. However, the prompting of information that certain states have loose gun control laws and high rates of gun violence actually decreases the likelihood that Republicans think that gun control laws are too strict, but has no impact for Democrats.

The results in this paper are consistent with the idea that emotional cues strengthen pre-existing biases towards gun control and gun rights, while informational cues sway people to become more moderate in their views on these issues. Of course, some caveats are important to mention. First, this survey was administered to high school participants, and the views of youth may be much more malleable than the views of the general population and an important question is whether the impact of cues and frames on survey responses of youth will actually lead to changes in adult behaviors such as voting. Granberg and Holmberg (1990) show that the correlation between intention to vote and actual voting is very high among U.S. and Swedish voters, though Hooghe and Wilkenfeld (2008) find more mixed evidence on the stability of attitudes and behavior over time. In addition, the results with respect to cues and framing of survey questions has been shown for one particular topic: school violence and gun rights/control. Whether or not these results would generalize to other age groups and for other public policy issues remains an open question. Nonetheless, in the current environment of polemicized and divisive discourse, there are potentially important implications of these results for the shaping of public opinions and debates between people of different political persuasions. Specifically, this results of this study show that providing objective information can be more helpful in narrowing the gaps in public opinions across political parties than appealing to one's emotions about pre-existing biases. In addition, policy makers must be critically aware of the effects that the framing of questions and the prompting of various types of information may have on the way people respond to surveys, particularly younger individuals that may still be in the process of formulating their beliefs on important policy issues. These effects may also interact with the effects of race, gender, and family income. Further research that explores these issues would be helpful in understanding the factors that shape voter attitudes.

Conflicts of Interest: The author declares no conflict of interest.

\section{References}

Brader, Ted. 2005. Striking a responsive chord: How political ads motivate and persuade voters by appealing to emotions. American Journal of Political Science 49: 388-405. [CrossRef]

Carmines, Edward G., John P. McIver, and James A. Stimson. 1987. Unrealized partisanship: A theory of dealignment. The Journal of Politics 49: 376-400. [CrossRef]

Carsey, Thomas M., and Geoffrey C. Layman. 2006. Changing sides or changing minds? Party identification and policy preferences in the American electorate. American Journal of Political Science 50: 464-77. [CrossRef] 
Chong, Dennis, and James N. Druckman. 2007. A theory of framing and opinion formation in competitive elite environments. Journal of Communication 57: 99-118. [CrossRef]

Cornelissena, Gert, Mario Pandelaere, Luk Warlop, and Siegfried Dewitte. 2008. Positive cueing: Promoting sustainable consumer behavior by cueing common environmental behaviors as environmental. International Journal of Research in Marketing 25: 46-55. [CrossRef]

Cox, Daniel, and Joanna Piacenza. 2015. Stark Political Division over Gun Control. Washington: Public Religion Research Institute.

Druckman, James N. 2001. Evaluating framing effects. Journal of Economic Psychology 22: 91-101. [CrossRef]

Druckman, James N. 2004. Political Preference Formation: Competition, Deliberation, and the (Ir)relevance of Framing Effects. American Political Science Review 98: 671-86. [CrossRef]

Ehman, Lee H. 1980. The American school in the political socialization process. Review of Educational Research 50: 99-119. [CrossRef]

Fedoroff, Ingri D.C., Janet Polivy, and C. Peter Herman. 1997. The effect of pre-exposure to food cues on the eating behavior of restrained and unrestrained eaters. Appetite 38: 33-47. [CrossRef]

Ferree, Myra Marx. 2003. Resonance and radicalism: Feminist framing in the abortion debates of the United States and Germany. American Journal of Sociology 109: 304-44. [CrossRef]

Flanagan, Constance A., Patricio Cumsille, Sukhdeep Gill, and Leslie S. Gallay. 2007. School and community climates and civic commitments: Patterns for ethnic minority and majority students. Journal of Educational Psychology 99: 421-31. [CrossRef]

Gadarian, Shana Kushner. 2010. The politics of threat: How terrorism news shapes foreign policy attitudes. The Journal of Politics 72: 469-83. [CrossRef]

Goren, Paul. 2005. Party identification and core political values. American Journal of Political Science 49: 881-96. [CrossRef]

Granberg, Donald, and Sören Holmberg. 1990. The Intention-Behavior Relationship among U.S. and Swedish Voters. Social Psychology Quarterly 53: 44-54. [CrossRef]

Haider-Markel, Donald P., and Mark R. Joslyn. 2001. Gun policy, opinion, tragedy, and blame attribution: The conditional influence of issue frames. The Journal of Politics 63: 520-43. [CrossRef]

Harris, Jennifer L., John A. Bargh, and Kelly D. Brownell. 2009. Priming effects of television food advertising on eating behavior. Health Psychology 28: 404. [CrossRef] [PubMed]

Hess, Robert Daniel, and Judith V. Torney-Purta. 1967. The Development of Political Attitudes in Children. Piscataway: Transaction Publishers.

Hooghe, Marc, and Britt Wilkenfeld. 2008. The Stability of Political Attitudes and Behaviors across Adolescence and Early Adulthood: A Comparison of Survey Data on Adolescents and Young Adults in Eight Countries. Journal of Youth and Adolescence 37: 155-67. [CrossRef]

Jacoby, William G. 2000. Issue framing and public opinion on government spending. American Journal of Political Science 44: 750-67. [CrossRef]

Johnston, Richard. 2006. Party identification: Unmoved mover or sum of preferences? Annual Review of Political Science 9: 329-51. [CrossRef]

Kleck, Gary. 1996. Crime, culture conflict and the sources of support for gun control. American Behavioral Scientist 39: 387-404. [CrossRef]

Kühberger, Anton. 1998. The influence of framing on risky decisions: A meta-analysis. Organizational Behavior and Human Decision Processes 75: 23-55. [CrossRef] [PubMed]

Kunda, Ziva. 1990. The case for motivated reasoning. Psychological Bulletin 108: 480-98. [CrossRef] [PubMed]

Laibson, David. 2001. A cue-theory of consumption. Quarterly Journal of Economics 116: 81-119. [CrossRef]

Malhotra, Neil, and Alexander G. Kuo. 2008. Attributing blame: The public's response to Hurricane Katrina. The Journal of Politics 70: 120-35. [CrossRef]

Mattes, Richard D. 1997. Physiologic responses to sensory stimulation by food: Nutritional implications. Journal of the American Dietetic Association 97: 406-13. [CrossRef]

Mueller, John E. 1994. Policy and Opinion in the Gulf War. Chicago: University of Chicago Press.

Niemi, Richard G., and M. Kent Jennings. 1991. Issues and inheritance in the formation of party identification. American Journal of Political Science, 970-88. [CrossRef]

Owen, Ann L., Emily Conover, Julio Videras, and Stephen Wu. 2012. Heat waves, droughts, and preferences for environmental policy. Journal of Policy Analysis and Management 31: 556-67. [CrossRef] 
Parker, Kim, Juliana Horowitz, Ruth Igielnik, Baxter Oliphant, and Anna Brown. 2017. America's Complex Relationship with Guns. Washington: Pew Research Center.

Pasek, Josh, Kate Kenski, Daniel Romer, and Kathleen Hall Jamieson. 2006. America's youth and community engagement: How use of mass media is related to civic activity and political awareness in 14- to 22-year-olds. Communication Research 33: 115-35. [CrossRef]

Payne, Brian K., and Robert Riedel. 2002. Gun control attitudes and the criminal justice student: Do differences exist? College Student Journal 36: 314-23.

Prior, Markus. 2010. You've either got it or you don't? The stability of political interest over the life cycle. The Journal of Politics 72: 747-66. [CrossRef]

Redlawsk, David P. 2002. Hot Cognition or Cool Consideration? Testing the Effects of Motivated Reasoning on Political Decision Making. Journal of Politics 64: 1021-44. [CrossRef]

Rohlinger, Deana A. 2002. Framing the abortion debate: Organizational resources, media strategies, and movement-countermovement dynamics. The Sociological Quarterly 43: 479-507. [CrossRef]

Sears, David O., and Carolyn L. Funk. 1999. Evidence of the long-term persistence of adults' political predispositions. The Journal of Politics 61: 1-28. [CrossRef]

Smith, Tom W. 1984. The polls: Gender and attitudes toward violence. The Public Opinion Quarterly 48: 384-96. [CrossRef]

Squires, Catherine R. 2011. Bursting the bubble: A case study of counter-framing in the editorial pages. Critical Studies in Media Communication 28: 30-49. [CrossRef]

Tversky, Amos, and Daniel Kahneman. 1981. The framing of decisions and the psychology of choice. Science 211: 453-58. [CrossRef] [PubMed]

Vogel, Rick. 2011. Framing and counter-framing new public management: The case of Germany. Public Administration 90: 370-92. [CrossRef]

Wang, An-Li, Dan Romer, Igor Elman, Bruce I. Turetsky, Ruben C. Gur, and Daniel D. Langleben. 2015. Emotional graphic cigarette warning labels reduce the electrophysiological brain response to smoking cues. Addiction Biology 20: 368-76. [CrossRef] [PubMed]

Wolpert, Robin M., and James G. Gimpel. 1998. Self-interest, symbolic politics, and public attitudes toward gun control. Political Behavior 20: 241-62. [CrossRef]

Zhang, Weiwu, Thomas J. Johnson, Trent Seltzer, and Shannon L. Bichard. 2010. The revolution will be networked: The influence of social networking sites on political attitudes and behavior. Social Science Computer Review 28: 75-92. [CrossRef]

(C) 2018 by the author. Licensee MDPI, Basel, Switzerland. This article is an open access article distributed under the terms and conditions of the Creative Commons Attribution (CC BY) license (http://creativecommons.org/licenses/by/4.0/). 